腄湯圭榷認した。

前回平川一梶谷等が報告した本疾患の 2 例注

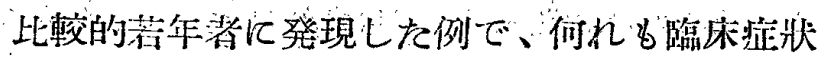
道に組織所見に於て子明妿に肉腄化えの移行像

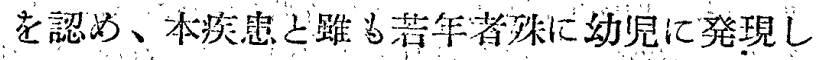

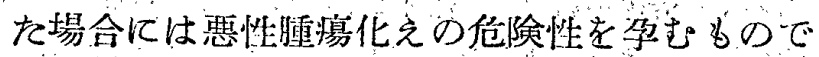

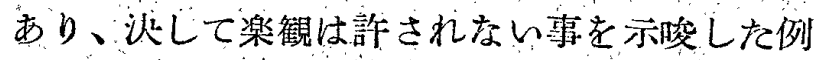
でする。

而るに本例では患者は己に成年に達してお り、郚床的には所謂良性腫瘍の態度を継続し、

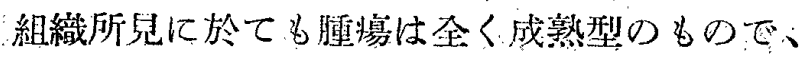
從つて予後に於て女経過は至極良好で、約 1 ; 年後の現在に至る女全く猉常老認めでいない。

\section{結 語}

1)本例は18才男子の左側下顎骨に発現し、

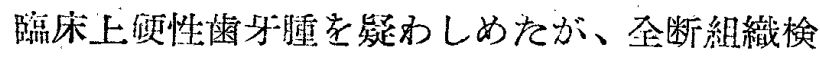
絜の結紧骨線維厘之確認された。

2）本例は本疾患としては比較的稀な下影発 現例である。

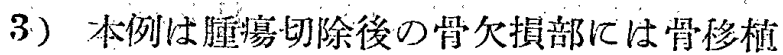
を行穖能を回復せしめた例でする。

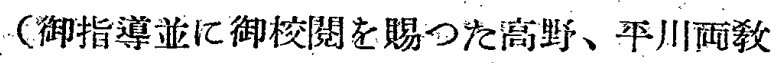
授に澡甚の謝意を表する。)

\section{主 要 文 献}

1) Menzel; Arch. f. Klin. Chirux. Bd. 13, (1872).

2) Uyeno; Beitr. Klin. Chirur. Bd. 65, (1909)

3) Hippel ; Ztschr. f. Mund U. Kief erchir. Bd. I. (1915)

4) Lexer ; Allgemeine Chirurgie, (1924)

5) Feldman ; D. M. F. Z. Heft. 12, (1928)

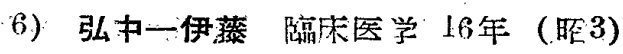

7) 後藤、海軍"軍医会雑誌 19卷3号 (1930)

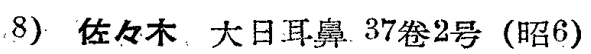

9) 岡 大日耳鼻 37 卷 12 号 (晊7)

10) Stafine; J. A. D. A. P. 1822 (1934)

11）広田大日闻鼻 40 卷11号 (㔭9)

12). 川野 東京医蚛 1415号 (昭9)

13) 大野 東京医誌 $290 \overline{0}$ (昭10)

14) 小野 口病誌 13 管 $I$ 号 (昭14)

15) 村賴，菡科学報 46 替 1 号（昭15)

16) 土佐林 耳鼻咽喉科 22爸9号（昭25)

17) 平川一梶谷，九州窲科学会雑誌 6 然2号

\title{
咽頍側壁、舌根部に瘾着せる 顎下部惡性腫瘍の一例
}

\author{
九州蒌科大学口腔外科学敉空（主任 平川正腪呚授） \\ 久‥原 勝之、古 野 秋 生 \\ 同 \\ 病理学郄室 (主任 高野義臣呚授) \\ 浦 缴篤史
}

緒:

言

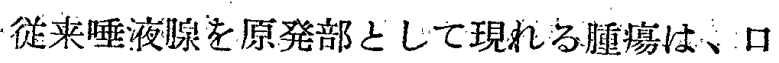

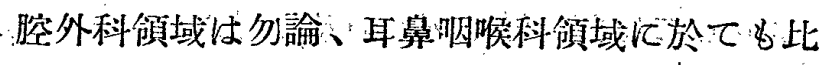
較的その頻度は少认。而して此等の腫演が恵性 化した敞告は更に僅少な発現率少している。

吾々は今回左側顎下唾液腺を原発栄として舌 根部、会厭軟滑附着部に癒着しだ墨性腫瘍の一

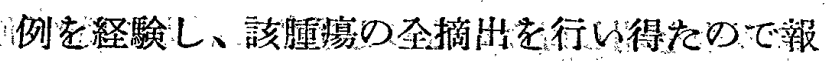

告する。

\section{臨 床 例}

患者栗○良○、48 方

初 訜和27年8月19日

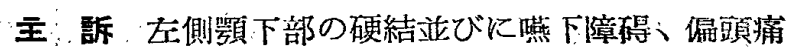

躰往病歷 特記すべき著患を認めない。

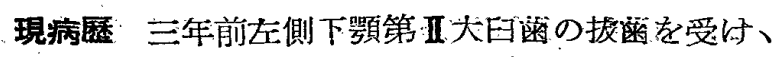

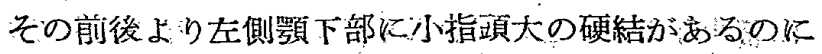


気付いていたが、自発痛がないので放置していた。今 年に大り詈下部の硬結が增大しているのに気付くと共 に左㑡下䂛第一巨四部に異常感があるので、該四牙の 拨去を受けたが何等の効なく、その後顎下部硬結は检

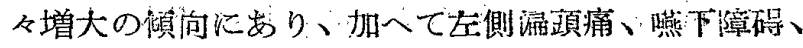
睡眠澺碍などが現れたので本院口腔外科を訪れた。

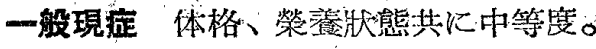

局所現症，顏貌は外観上異常はない。触竞するに左

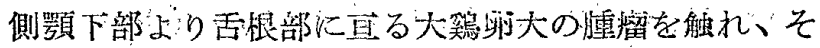

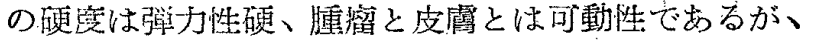

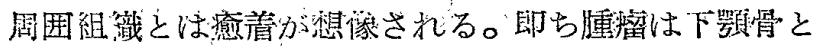

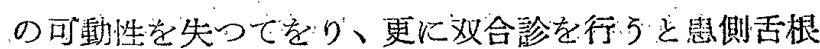

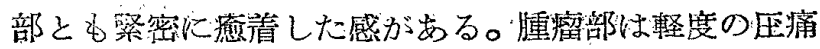
があるが、該部皮虚の発赤、熱感などは認めない。口

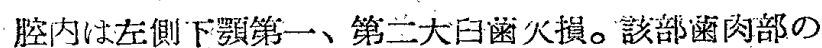
発赤、腫脤などばない。舌根部を触診すると前述の吝 く舌根と金く可動性を笑つた腫瘤を触れる。懁下痛を 訴へるが、牙関漗急は認めない。

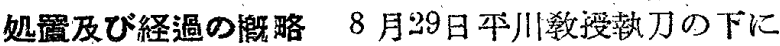

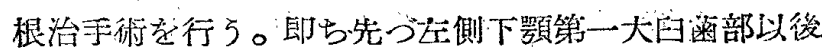
の下顎骨を補助的に関節離断の下に切除し、次いで睡

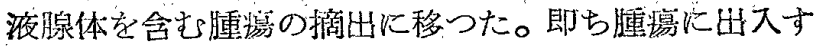

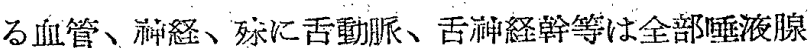
体を含む䛲場を通邀していたので之等は全部結禁切断 しつ〉樑部に向い䟝離を進めたが内側に拎ては舌根

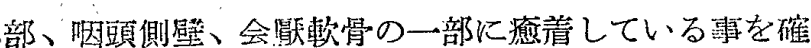

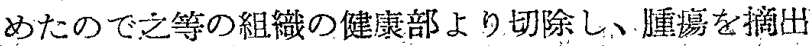
した。

\section{病理組織學的所見}

摘出腫溜は通法に従いCelloidin 全断連続切片と し、Haematoxylin-Eosin 染色设び van-Giesun 染他 を行つた。腫殉笑質は組織学的に相買る二つの細胞群 によつて構成されている。

1. 細胞は紡錐形乃至膜円形を呈し胞体の境羿は鮮 明。一般に可成り異型性を呈する。此の細胞は基貿中 に不規則に索狀比增殖し、境界䟚利な大小の管腔を形 成している。又一部のるのは集団をなし癌腫の感を呈 し、線維の介在は全く見られず、变性沁陷つた腫搨細 胞む敖見せられ、又管内腔比 Eosin 物筫乃至血液を充しているものもむる。之は内皮腫の 像と思はれる。

2. 細胞は骰子形乃至多角形。核は大きく、染色性

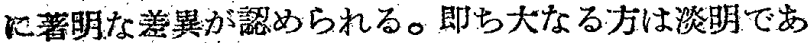

り。二阔或ひは一個の核小体は鮮期、小なる方は隂渠 して核小体は不鮮明。此の細胞は腺形成像が著明であ り、或るむのは腔内に充夹性に堌殖してをり、㕛或る ものは小管腔を中心K成線狀の配列を示すももある。

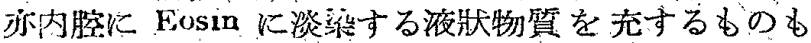
ある。一部の唾液湶小某闪认は高度の形質細胞、淤巴 球の浸潤があり、残存する腺細胞は区迫萎漷々陮り、 或るぬのは前癌装化と思はれる像を呈している。之は 顎下唾液腺々複と思はれる。

腫愓の大部分は著明に增殖した結合織線維によつて 構成されている。特に中心部认於て著胉であるが、膠 原線緇の多くは硝子様化し核が消失している。腫演辺

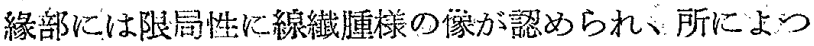
ては間質内に出血が見られる。矎着した淋巴腺は增殖 した腫䄈紐胞によつて压迫されてをり、血管の充盈が

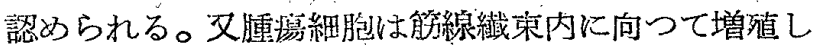

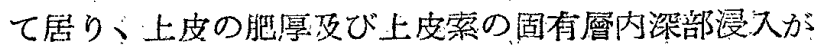
見られた。

\section{考按}

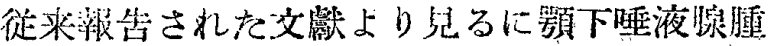

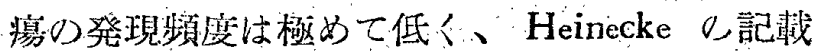

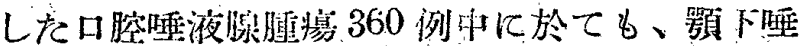

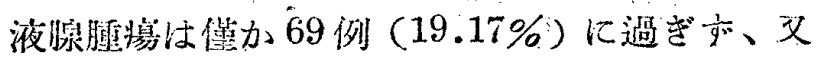

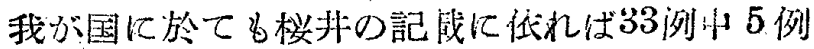
を般告している位である。殊に道科口腔外科領

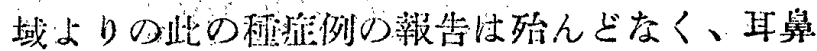
呕喉湖領域に於て少数例の船告を見るのみであ

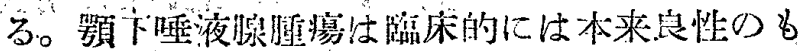
のが多く其の発育も緩慢上されているが、悪性 化する時注速やかな発育をなし、淋巴行又怯血 行による転栘を招来するるのである。Küttner

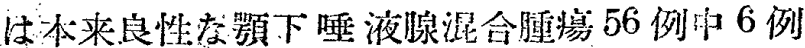
(11\%) に舆性化した事を記载している。我々 の今回の症例柱左測唾顎下液腺に同時に生じを と思はれる腺瘫と內皮組施腫であり、前述の点 上りして比較的稀交例であると思ふ。

次に本例の摘出手衔に際しては、腫瘍がすで

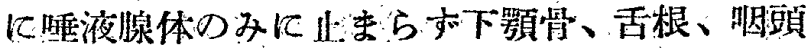
壁に癒省移行が予想されたため、顎下部切開の

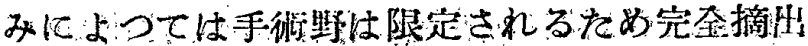
に万全期し得李いる。と矛想し、更に悪性腫 


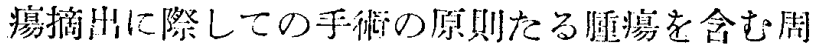

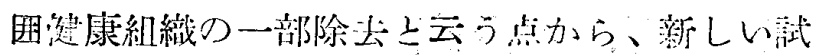

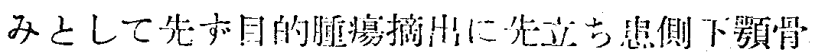

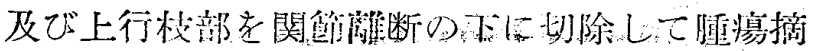

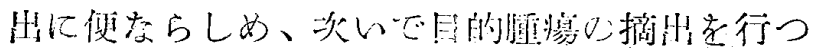

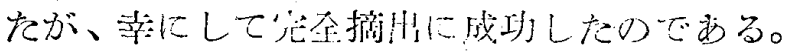

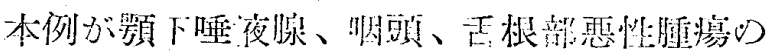

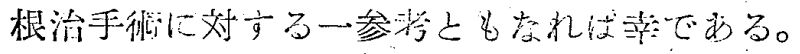

結論

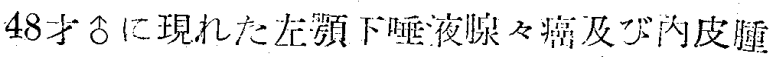

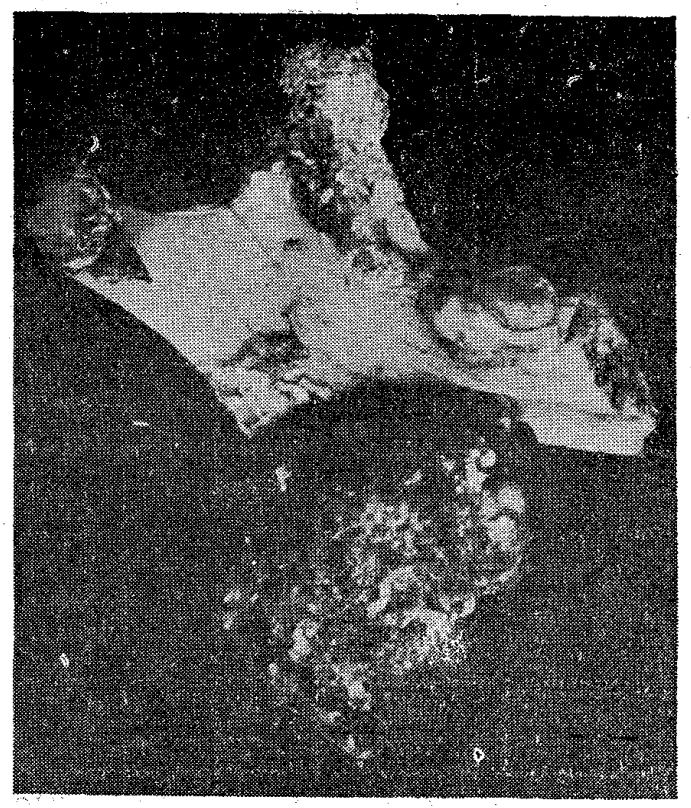

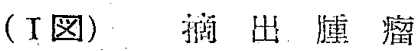

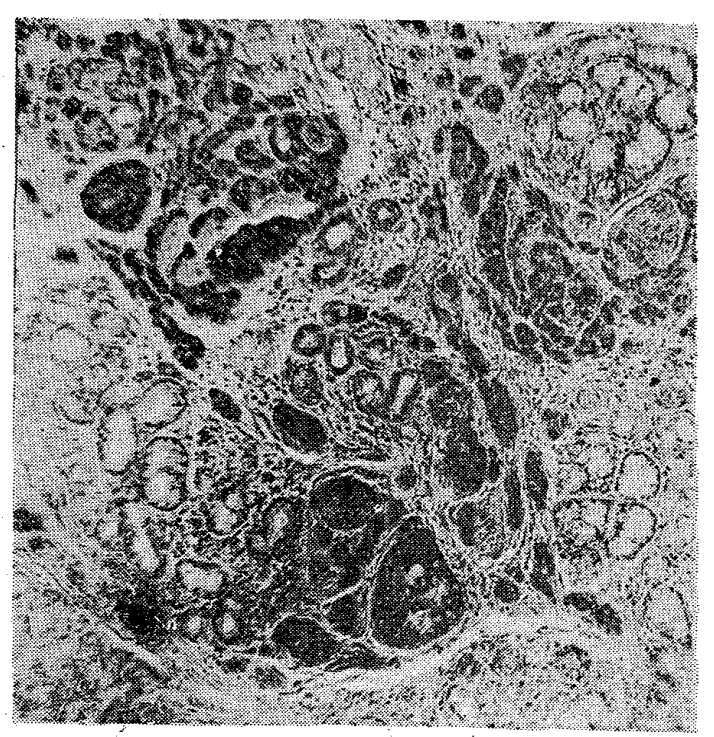

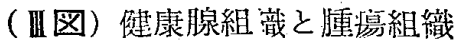

$(\mathrm{H}-\mathrm{E}$ 染色、 $\times 73)$

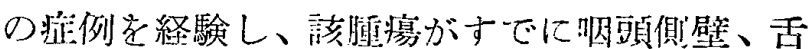

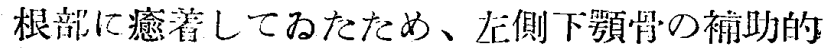
切除により完全摘中をなし得たものである。

\section{參 考 文 献}

1）池谷澄夫 東京医事新誌 3094号（昨13）

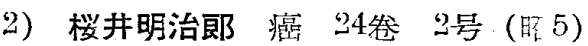

3) Küttner; Beitr. 7. Kl. Chir., Bd. 16 (1896)

4) A, Fraser ; Dent, Cos., Vol. fio, No.8, (1918)

5) N. Swinton \& S. Warren; J. A. D. A., VOl. $25, \quad(1938)$

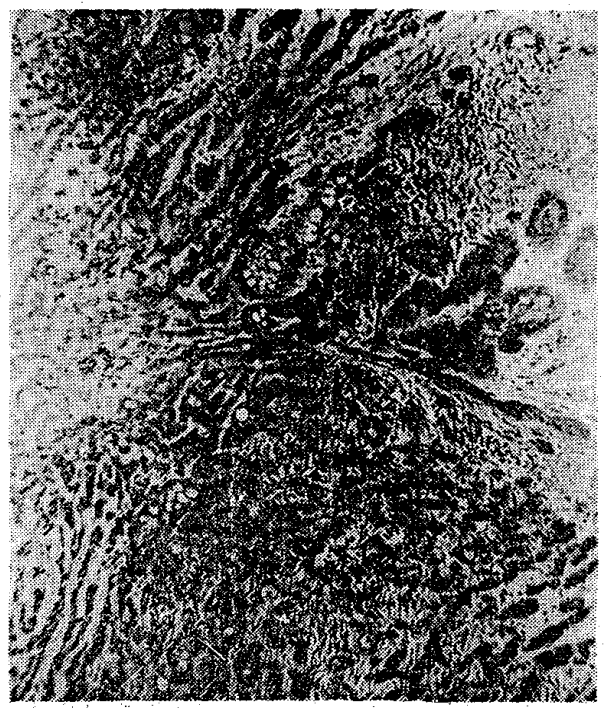

（J図）內皮腫像（H-E E 染色、 $\times 73)$

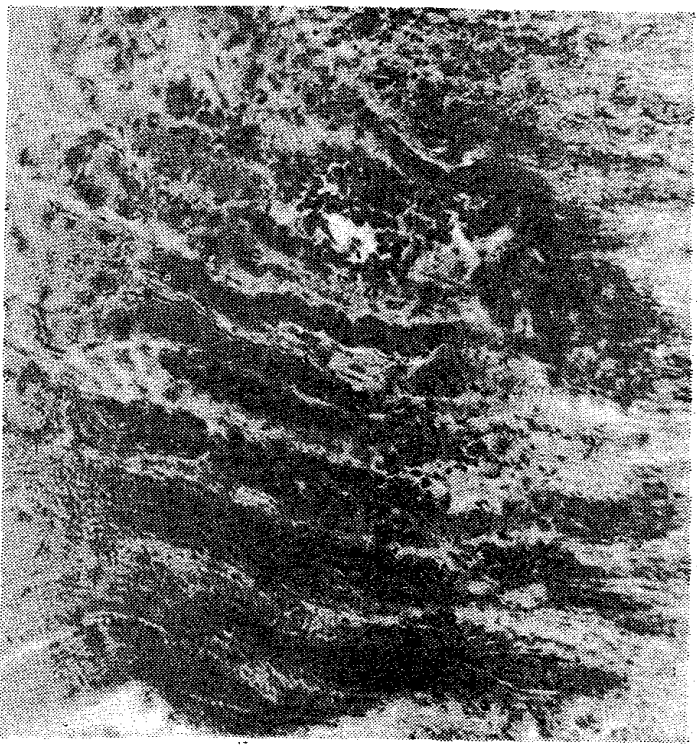

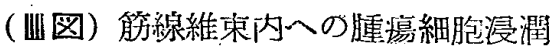
$(\mathrm{H}-\mathrm{E}$ 染色、 $\times 140)$ 